Research

\title{
Identification of Extension Methods Based on Local Wisdom to Increase Public Awareness and Understanding of Antimicrobial Control
}

\author{
Mashur $^{1 *}$, Kholik ${ }^{2}$, Dina Oktaviana3, Muhammad Munawaroh ${ }^{4}$, \\ Muhammad Rama Imam Saputra ${ }^{5}$, Siti Nurus Sa'diyah ${ }^{6}$ \\ 1,3 Departement of Feed, Nutrition and Social Economic, Faculty of Veterinary Medicine, \\ Pendidikan Mandalika University \\ 2,4 Departement of of Animal Infectious Diseases and Veterinary Public Health, \\ Faculty of Veterinary Medicine, Pendidikan Mandalika University \\ ${ }^{5}$ Veterinary Teaching Hospital, Faculty of Veterinary Medicine, Pendidikan Mandalika University \\ ${ }^{6}$ Student of Faculty of Veterinary Medicine, Pendidikan Mandalika University \\ *Corresponding author: mashurntb40@gmail.com \\ Submitted March 27, 2021 Accepted April 30, 2021
}

\begin{abstract}
The number of people experiencing antimicrobial resistance continues to increase from year to year it can be a global threat to public health and animal health that can have an impact on the sustainability of the agricultural sector, food security, and environmental security. One of the contributing factors is the lack of public awareness and understanding of the dangers of antimicrobial resistance. For that, we need efforts to increase outreach activities to the community. This study aims to identify the most effective local wisdom- based extension methods for increasing public awareness and understanding of antimicrobial control. The research was conducted using a survey method from September to December 2020 in 10 districts/cities in West Nusa Tenggara. The number of respondents was 71 people determined by positive random sampling. Data were analysis descriptively based on frequency distribution data. The results showed that there were 45 types of extension media that could be used to convey information on antimicrobial control, namely: media extension based on local wisdom as much as 59.15\%; conventional extension media $35.21 \%$ and modern extension media 5.64\%. Extension methods that are effectively applied are extension methods with an $80 \%$ group approach; direct communication $86.67 \%$ and extension methods with a combination of 91.11\% senses. The conclusion is that the local wisdom-based extension method is the most effective method with a group approach, direct communication and uses a combination of the senses of acceptance (sight, hearing, touch, taste, and smell).
\end{abstract}

Keywords: antimicrobial control, extension methods, local wisdom, public awareness

\begin{abstract}
ABSTRAK
Jumlah penduduk yang mengalami resistensi antimikroba terus meningkat dari tahun ke tahun, sehingga dapat merupakan ancaman global bagi kesehatan masyarakat dan kesehatan hewan yang dapat berdampak terhadap keberlangsungan sektor pertanian, keamanan pangan dan keamanan lingkungan. Salah satu faktor penyebabnya adalah rendahnya kesadaran dan pemahaman masyarakat tentang bahaya resistensi antimikroba. Untuk itu diperlukan upaya peningkatan kegiatan penyuluhan kepada masyarakat. Penelitian ini bertujuan mengidentifikasi metode penyuluhan berbasis kearifan lokal yang paling efektif untuk meningkatkan kesadaran dan pemahaman masyarakat dalam pengendalian antimikroba. Penelitian dilakukan dengan metode survai pada bulan SeptemberDesember 2020 pada 10 kabupaten/kota di Nusa Tenggara Barat. Jumlah responden sebanyak 71 orang ditetapkan secara porposive random sampling. Data dianalisis secara diskriptif berdasarkan data distribusi frekuensi. Hasil penelitian menunjukkan terdapat 45 jenis media penyuluhan yang dapat digunakan untuk menyampaikan informasi pengendalian antimikroba, yaitu: media penyuluhan berbasis kearifan lokal sebanyak 59,15\%; media penyuluhan konvensional $35,21 \%$ dan media penyuluhan modern 5,64\%. Metode penyuluhan yang efektif diterapkan adalah metode penyuluhan dengan pendekatan kelompok $80 \%$; komunikasi langsung $86,67 \%$ dan metode penyuluhan dengan kombinasi indera penerima $91,11 \%$. Simpulannya adalah metode penyuluhan berbasis kearifan lokal merupakan metode yang paling efektif dengan pendekatan kelompok, komunikasi langsung dan menggunakan kombinasi indera penerimaan (pengelihatan, pendengaran, perabaan, pengecapan dan penciuman).

Kata kunci: kearifan lokal, kesadaran dan pemahaman masyarakat, metode penyuluhan pengendalian antimikroba
\end{abstract}


110 | Mashur et al.

\section{INTRODUCTION}

Antimicrobial resistance (AMR) can affect not only human health, but also the health of animals, and the surrounding environment. So that it can affect the sustainability of the agricultural sector, food security and environmental security. The death rate due to antimicrobial resistance (AMR) until 2014 was recorded at around 700,000 people per year and the number of livestock that died was also quite a lot. With the rapid development and spread of infections due to resistant microorganisms, it is estimated that by 2050 the deaths from antimicrobial resistance will be greater than the deaths from cancer of around 8 million. The number of people who are resistant is estimated at 10 million people/ year in total Gross Domestic Product (GDP) which was lost about 100 trillion dollars. If this is not immediately anticipated, it will have negative impacts on health, the economy, food security, and global development, including burdening state finances (WHO, 2015).

Studies in European countries show that resistance to antibiotic drugs increases in proportion to the increase in consumption, due to irrational use of antibiotics and inadequate public education (Ferri et al., 2017). Besides, public insight about antibiotics or antimicrobials is very limited they are less aware of the side effects of unwanted drug reactions. Many people are given antimicrobials in the form of antibiotics from health workers when they seek treatment and stop taking them without the doctor's knowledge. Health workers also sometimes give incorrect doses and misdiagnoses. Therefore, people must have an understanding or knowledge of antimicrobials so that they and their families are more aware of using antimicrobials. Public knowledge about the use of antibiotics is still low, resulting in high irrational use. Lack of public understanding and knowledge of the correct and appropriate use of antibiotics is a trigger factor for bacterial resistance to antibiotics.

Considering the complexity of the problems that occur and the impacts caused by AMR, it is necessary to control efforts involving all components of society in a coordinated, integrated and integrated manner. Extension activities are activities that can be carried out to be a solution to controlling AMR for the community. Health extension is a form of educational activity that can influence knowledge and attitudes. With the existence of educational activities in the form of extension, the community will get learning and information so that behavior changes (knowledge and attitudes) occur. Health extension is an educational activity carried out by sharing messages, instilling confidence so that people are not only aware, know and understand, but also want and can do something recommended that has side effects on health. Health education is a combination of various activities and opportunities based on the principles of learning to achieve a situation, where individuals, families, groups, or communities totally want to live healthily and know how to do what can be done individually or as a group. Therefore, extension activities need to be continuously developed as a means of supporting the success of antibiotic resistance control efforts. In connection with this, research has been carried out to identify extension media based on local wisdom so that the implementation of extension can give optimal results.

This study aims to: (1) identify types of extension media based on local wisdom that can be used as extension media to increase public awareness and understanding of antimicrobial control efforts and (2) identify the most effective extension methods that can be used to deliver extension materials concerning efforts to control antimicrobials based on local wisdom to increase public knowledge and attitudes towards the wise use of antimicrobials.

\section{MATERIAL AND METHODS}

Research to find out which media and extension methods are most effective based on local wisdom has been carried out using a survey method which is complemented by a questionnaire in 10 districts/cities in West Nusa Tenggara Province on September-December 2020. The interviewed respondents were students of the Faculty of Veterinary Medicine (FKH) of the Pendidikan Mandalika Mataram University who were in their respective villages during the Work from Home (WFH) period or studying from home during the Covid-19 pandemic. The number of respondents was determined using of purposive random sampling with the criteria of respondents coming from different student domicile villages in all regions in West Nusa Tenggara. The number of respondents was 71 people representing 245 villages $(21.43 \%$ ) of the 1,143 villages in West Nusa Tenggara (BPS NTB, 2018) which were calculated based on the formula $\mathrm{n}=\mathrm{N} / 1+\mathrm{Ne} 2 \mathrm{Ka}$ vanagh, 2011). Information $n=$ number of respondents based on the student's domicile village; 
$\mathrm{N}=$ total population (number of villages); and $\mathrm{e}=$ acceptable error (10\%). The data were tabulated using the Excel program and analysis descriptively. The data collected is the type of media or container that can be used as an extension channel to convey information about antimicrobial control efforts. The data is grouped into three, namely local wisdom-based extension media in the village; conventional extension media, and modern media based on information technology (digital). The identified data on the most effective extension methods were divided into three groups, namely extension methods based on the number of extension targets (individual, group, and mass).

Based on descriptive data analysis, it will be possible to identify types of extension media based on local wisdom that can be used to deliver extension materials on antimicrobial control efforts to increase public awareness and understanding. Through this research, it can also be seen that the most effective extension methods for delivering extension materials on antimicrobial control efforts.

\section{RESULTS AND DISCUSSION}

\section{The Most Widely Selected Extension Media}

The results of the research in Table 1 show that of the 45 types of extension media that can be identified, there are 29 types of media (64.44\%) which are local wisdom-based extension media with the number of respondents who chose this media as much as $59.19 \%$. The number of identifiable conventional extension media was $28.89 \%$ and the number of modern information-technologybased (digital) extension media was 6.67\%. The results identification of the types of extension media that can be used to deliver extension material on antimicrobial control is shown in Table 1.

The data in Table 1 shows that the extension media chosen by most respondents in delivering extension materials on antimicrobial control is local wisdom-based extension media with a total number of respondents voting as much as $59.15 \%$ with 29 types of media, while conventional extension media was chosen by $3521 \%$ of respondents with the number of media selected were 13 types of

\begin{tabular}{|c|c|c|c|c|}
\hline No & $\begin{array}{l}\text { Extension Media } \\
\text { Group }\end{array}$ & $\begin{array}{l}\text { Types of media that can be used to } \\
\text { deliver extension materials }\end{array}$ & $\begin{array}{l}\text { Number } \\
\text { of media } \\
(\%)\end{array}$ & $\begin{array}{c}\text { Number of } \\
\text { respondents } \\
\text { who voted (\%) }\end{array}$ \\
\hline 1 & $\begin{array}{l}\text { Extension media based } \\
\text { on local wisdom }\end{array}$ & $\begin{array}{l}\text { Student associations/communities, hamlet youth, } \\
\text { youth groups, scouts, posyandu, weekly recita- } \\
\text { tion, mosque youth, art studios, Friday meetings } \\
\text { (meetings after Friday prayers), hadrah team, } \\
\text { youth volleyball community, Al-Quran garden su- } \\
\text { pervisors, community leaders, figures religion, } \\
\text { traditional leaders, weekly serakalan associations, } \\
\text { angler mania, yasinan groups, traditional markets, } \\
\text { buffalo karapan communities, dharma wanita } \\
\text { gathering, prayer groups at mosques, regenera- } \\
\text { tion schools (accordance), village extension la- } \\
\text { boratories, fishermen groups, farmer groups, } \\
\text { livestock groups, successful farmers, traders }\end{array}$ & $\begin{array}{c}29 \\
(64.44)\end{array}$ & $\begin{array}{c}42 \\
(59.15)\end{array}$ \\
\hline 2 & $\begin{array}{l}\text { Conventional } \\
\text { extension media }\end{array}$ & $\begin{array}{l}\text { Village-to-village socialization, socialization at the } \\
\text { boarding school, socialization at the village hall, so- } \\
\text { cialization at schools, use of farmers' spare time, } \\
\text { home visits, training, farming courses, talk shows, } \\
\text { screenshots, posters, mobile advertising, gathering }\end{array}$ & $\begin{array}{c}13 \\
(28.89)\end{array}$ & $\begin{array}{c}25 \\
(35.21)\end{array}$ \\
\hline 3 & $\begin{array}{c}\text { Modern } \\
\text { information technology- } \\
\text { based extension }\end{array}$ & $\begin{array}{l}\text { Written education through websites, social media, } \\
\text { radio broadcasts }\end{array}$ & $\begin{array}{c}3 \\
(6.67)\end{array}$ & $\begin{array}{c}4 \\
(5.64)\end{array}$ \\
\hline & Total & & 45 & 71 \\
\hline
\end{tabular}


media and modern information-technology-based (digital) media were only chosen by $5.64 \%$ of respondents with 3 types of selected media.

Based on the data in Table 1, it appears that the use of extension media based on local wisdom is preferable to be a medium for an extension to convey information on antimicrobial control for the community. Based on the results of the research in Table 1, it appears that the extension media that is mostly chosen by respondents to deliver extension materials to increase public awareness and understanding of antimicrobial control is extension media based on local wisdom. There are $29(64.44 \%)$ types of extension media based on local wisdom from 45 types of extension media identified in this study that can be selected as extension media to deliver extension materials on anti- microbial control.

The number of respondents who chose local wisdom-based extension media was $59.15 \%$ or the ratio of the number of extension media to respondents who chose it was 1.45. For conventional extension media groups there are 13 types of media (28, 89\%) the number of respondents who chose this media was $35.21 \%$ with a ratio of 1.92 and for the modern information technology-based (digital) media group there were only 3 (6.67\%) types of media Extension which can be the choice of the media in delivering extension material on antimicrobial control to the public with the number of respondents who chose it was $5.64 \%$ with a ratio of 1.33 . Based on the data in Table 1, it can be concluded that the local wisdombased extension media group is the most widely used media and the most chosen by respondents to be the extension media to increase public awareness and understanding of antimicrobial control. This is because the local wisdom-based extension media is a place or channel for an extension that grows and develops in the community, so that it has roots in the social, economic, and cultural conditions of the community. This is an extension media can be in the form of associations, communities, groups, associations of parents, youth, and housewives, both men and women, both in villages, and cities. These forums or communities hold periodic meetings according to their needs (time availability, issues to be discussed) so that they can be used as a medium of extension to convey information about antimicrobial control.

In addition to large number of media, the number of members of each association is also a large so that the dissemination of antimicrobial control information to the public will be faster with a wider reach. In terms of financing, organizing extension through local wisdom- based extension media does not require a large amount of money, because this forum already has regular activities. From the aspect of educational background, age, social standard and economic status, the use of media based on local wisdom varies greatly depending on the type of media, so the selection of this type of extension media needs to be adjusted to the needs and methods of extension used. Following the research results In terms of financing, organizing extension through local wisdom-based extension media does not require a large amount of money, because this forum already has regular activities. This is following the research results so that the selection of this type of extension media needs to be adjusted to the needs and methods of extension used. Following the research results Nurmala (2020). There is no significant relationship between knowledge of antibiotic drug use with age and education, but there is a significant relationship between knowledge of antibiotic drug use with gender and occupation.

\section{The Most Effective Extension Method}

The success of the implementation of antimicrobial control extension, apart from being influenced by the type of media used, is also largely determined by the selection of extension methods that are following the needs of the community as the final target of the extension. The research data in Table 1 shows that based on the number of extension targets, the group extension method is the most effective method of extension with 36 media of choice of extension media (80\%), when compared to the individual extension method with 6 types of media $(13,33 \%)$ or mass extension methods with 3 types of media (6.67\%), as shown in Figure 1.

Based on the communication technique, the extension method with direct communication techniques is the most widely chosen by the respondents with 39 types of media using direct communication techniques (86.67\%), while with indirect communication techniques there are 6 types of media (13.33\%) as shown in Figure 2.

Based on Table 1, the most effective extension method for delivering extension materials on antimicrobial control to increase public awareness and understanding is a combination of the senses of the target recipient of the extension (sight, hearing, taste, smell and touch) with 41 types of media $(91,11 \%)$ 


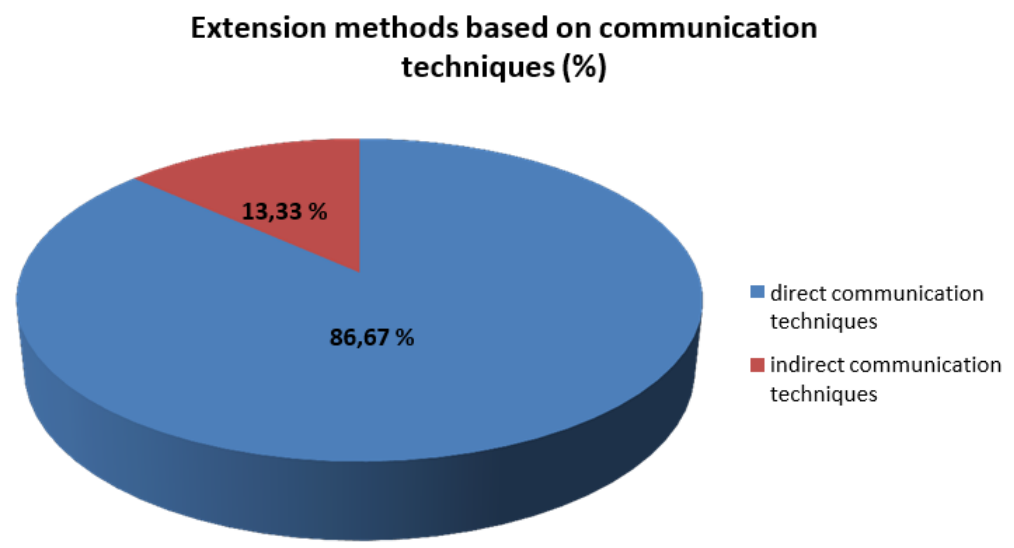

Figure 2 Extension methods based on communication techniques

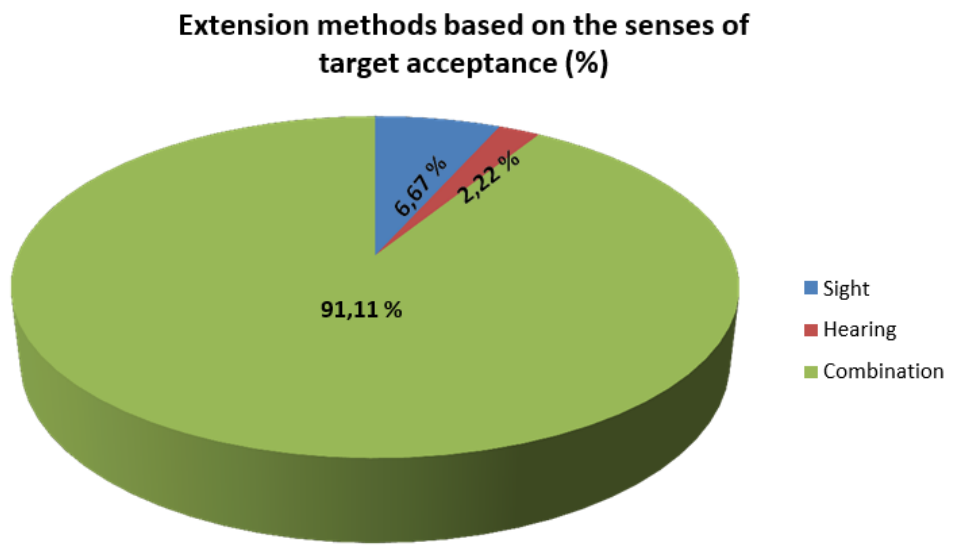

Figure 3 Extension methods based on the senses of target acceptance

through the sense of sight alone 3 types of media (6.67\%), and through the sense of hearing only one type of media (2.22\%), as shown in Figure 3.

Based on the extension method chosen by the most respondents, the extension method with the group approach is the most effective, as shown in Figure 1. Based on the selected media, $80 \%$ of the extension media chose extension methods with a group or community approach. This is following the results of research by Pratiwi et al. (2016) that group education is also able to increase public knowledge about drug information. Oh et al. (2011) also suggested that knowledge and attitudes towards antibiotics in society play an important role in the success of the treatment process. Changes in knowledge about the use of antibiotics can prevent resistance problems.

There were $13.33 \%$ voters for the individual extension method and only $6.67 \%$ who chose the mass extension method. Individual or individual extension methods are an extension method that is effective, but not efficient because it requires a lot of money and time and the reach of extension targets is limited. Thus, the holding of individual extension is rarely carried out. Mass extension methods are also rarely used because they are less effective. Through the mass extension method, the material provided is very limited, only as a general and brief preliminary information. This is following the results of Mashur's (2017) research on the selection of the most effective extension methods to convey information on efforts to prevent Anthrax disease in smallholder cattle farming in West Nusa Tenggara to support West Nusa Tenggara Province as the world's best halal tourist destination depending on the target of extension.

If the number of targets is very large or mass, then the general meeting extension method (mass meeting) is the most effective. If the target number of extension is in the form of a limited group of up to 20 people, then the group discussion extension method is the most effective method for delivering 
information about prevention of anthrax disease. If the target of the extension is individual.

Based on extension communication techniques, of the 45 types of extension media, there are $86.67 \%$ of the chosen extension media are extension media using extension methods with direct or face-to-face communication techniques. Although currently, the community is in the period of the Covid-19 pandemic, the application of extension methods with direct communication techniques can be carried out based on the Covid-19 health protocol, including using masks, adjusting distance, and washing hands with soap. Some examples of local wisdom-based extension media that use extension methods with direct communication techniques include student association/community meetings, hamlet youth, youth groups, youth scouts, posyandu, weekly recitation, mosque youth, art studios, Friday meetings (meetings after Friday prayers), hadrah team, youth volleyball community, coaches of Al-Quran Development Park, community leaders, religious leaders, traditional leaders, weekly serakalan associations, fishing mania, yasinan groups, traditional markets, karapan buffalo community, community groups of women Dharma Wanita, recitation groups in mosque, regeneration school, village extension laboratories, fishermen groups, farmer groups, farmer groups, successful farmers, merchant communities. By Astuty's research results (2019).

Face-to-face extension and providing direct information are expected to be more effective than extension through mass media or leaflets. The effectiveness of extension can be determined by measuring the level of knowledge carried out before and after extension so that changes in the level of public knowledge can be identified. The results of this study are following the results of research by Mashur et al. (2018) that other individual extension methods are most effective based on the number of scores and the number of respondents who rated individual learning, telephone calls, SMS, and correspondence. Meanwhile, based on the score, the most effective extension methods are home visits, individual study, telephone calls, face book (FB), and BBM. The individual method has a $17-18 \%$ effect on all methods. Individual relationships are needed so that farmers apply the recommended recommendations (Isnaini, 2015).

Based on the extension method with the target senses approach, the choice of the combination of the target recipient's sensory extension method is the most chosen, reaching $91.11 \%$ of all identified extension media, as shown in Table 1 and Figure 3. This means that the extension method the most effective is the extension method that uses a combination of existing extension media according to community needs. A combination of extension methods to increase public awareness and understanding of antimicrobial control can be a combination of extension media that can be seen, heard, touched, tasted, and smelled. For example, through the socialization of antimicrobial control methods to millennials through youth mosque associations equipped with demonstrations on how to use antibiotics wisely. This is in accordance with the results of research by Mashur et al. (2020) showed that $9.69 \%$ of respondents chose a showcase technology as the most effective method of dissemination; $8.6 \%$ chose field day meetings and $8.59 \%$ chose exhibition. Based on the dissemination method group, the technology demonstration was the most effective with $7.61 \%$ of respondents choosing; $6.9 \%$ interpersonal communication and $5.0 \%$ information dissemination. The conclusion is that none of the respondents chose only one method of dissemination that was the most effective, but most of them chose a combination of the three groups of dissemination methods.

Based on the results of this study, it can be concluded that the most widely chosen extension media to increase public awareness and understanding of antimicrobial control are local wisdom- based extension media with 29 types of selected extension media and use group extension methods carried out directly (face to face) using protocols Covid-19 health and by applying extension methods based on a combination of the target recipient's senses of extension involving the senses of sight, hearing, touch, smell and taste.

"All authors declare that there are no conflicts of interest".

\section{ACKNOWLEDGEMENT}

Acknowledgments are conveyed to the first semester students of the Faculty of Veterinary Medicine, University of West Nusa Tenggara 2020 who took the Animal Science course which has helped in collecting data in the field, so that this research can be carried out properly. I also express my special thanks to Siti Nurus Sa'diyah who helped translate this article 


\section{REFERENCE}

Astuty EJTA. 2019. Pengaruh penyuluhan terhadap tingkat pengetahuan tentang penyakit Rabies pada siswa Sekolah Dasar di Provinsi Sumatra Barat. Skripsi S1. Fakultas Kedokteran Hewan, Institut Pertanian Bogor. Bogor.

[BPS] Badan Pusat Statistik Provinsi Nusa Tenggara Barat. 2018. Jumlah desa di Provinsi Nusa Tenggara Barat.bps@go.id. Download: February 12, 2021.

Ferri M, Ranucci E, Romagnoli P, Giaccone V. 2017. Antimicrobial resistance: A Global Emerging Threat to Public Health Systems. https://pubmed. ncbi.nlm.nih.gov/?term=Ferri+M\&cauthor_id= 26464037. Download January 29, 2021.

Isnaini. 2015. Metode Penyuluhan Pertanian. https://alamindahsemesta.wordpress.com/2015/0 1/29/ metodepenyuluhanpertanian/ Download January 29, 2021.

Kavanagh P. 2011. Rapid appraisal of fisheries (Rapfish) project. Rapfish software description (for microsoft excel). University of British Columbia, Fisheries Centre, Vancouver

Kementrian Kesehatan Republik Indonesia. 2015. Peraturan Menteri Kesehatan Republik Indonesia No 8 Tahun 2015: Program Pengendalian Antimikroba di Rumah Sakit. Kemenkes RI. Jakarta.

Mashur. 2017. The Effective Extension Methods for Prevention of Anthrax Diseases on Smallholders Farming in Supproting West Nusa Tenggara Province as A World Halal Tourism Destination. http://eprints.unram.ac.id/10219/1/Artikel\%20Proc eeding\%200f\%202nd\%20ICST\%202017.pdf. Download: February 122021
Mashur, Kholik, Munawarah, Atma CD. 2018. The Most Effective Extension Methods to Prevent Influenza Avian Disease on Small Holders Farming in Tourism Destination Nusa Tenggara Barat. https://img1.wsimg.com/blobby/go/16ecgef68d34-4028-9140-3dde7d8c4bd8/downloads/ 2.\%20MASHUR.pdf?ver=1563409750157. Download: February 13, 2021

Mashur, Hunaepi, Oktaviana D, Kholik, Tirtasari K, Jannah M. 2020. Metode diseminasi teknologi hasil penelitian menurut peternak sapi potong di Nusa Tenggara Barat. The 2th National Conference on Education, Social Science, and Humaniora Proceeding 2 (1): 13-20

Nurmala S, Gunawan DO. 2020. Pengetahuan penggunaan obat antibiotic pada masyarakat yang tinggal di Kelurahan Babakan Madang. Jurnal Ilmiah Farmasi (10) 1: 22-31

Oh AL, Hassali MA, Al-Haddad MS, Sulaiman SA, Shafie AA, Awaisu A. 2011. Public knowledge and attitudes towards antibiotic usage: $A$ crosssectional study among the general public in the state of Penang, Malaysia. J Infect Dev Ctries 5(5): 338-347.

Pratiwi H, Nuryanti, Utami VV, Warsinah, Sholihat NK. 2016. Pengaruh edukasi terhadap pengetahuan, sikap, dan kemampuan berkomunikasi atas informasi obat. Kartika-Jurnal Ilmiah Farmasi (4)1: 10-15.

WHO. 2015. GlobalActionPlanonAntimicrobialResistance.http://www.emro.who.int/health-topics/ drug-resistance/global-action-plan.html\#: : text $=$ Global\%20Action\%20Plan\%200n\%20Antimicrobial $\% 20$ Resistance $\% 20$ (2015)Antimicrobi al\%20 resistance $\% 20$ (,enduring\%20threat\%20from $\% 20$ infe ctious\%20disease. Download: February 13, 2021 